\title{
EL PRIMER RELATO DE SEVERO SARDUY
}

\author{
POR \\ ROBERTO GONZALEZ-ECHEVARRIA \\ Yate University
}

Es curioso notar cómo conviven en un mismo escritor, en un mismo momento de su carrera, las tendencias más diversas y hasta contrarias. Y no menos curioso resulta leer la obra más temprana de un escritor y descubrir allí lo que parecen ser premoniciones muy específicas de lo que será su obra madura. No me refiero a la calidad de ésta, sino a estructuras, giros, personajes y obsesiones que sugieren la presencia de un hilo continuo, que se pega obstinadamente a las suelas del escritor por muy lejos que lo lleven sus pasos. Este es, al parecer, el caso de «El seguro», el primer relato publicado por Severo Sarduy, que salió en el semanario ilustrado cubano Carteles el 18 de agosto de $1957^{\prime}$. El relieve alcanzado por Sarduy posteriormente autoriza el rescate de este relato olvidado, que nos permitirá especular sobre las cuestiones planteadas acerca de la continuidad de una obra y sobre la obra de Sarduy en general, muy en particular su relación con las tendencias literarias de la Cuba de fines de los cincuenta y principios de los sesenta.

${ }^{1}$ En «Son de La Habana: la ruta de Severo Sarduy», en Revista Iberoamericana, núms. 76-77 (1971), escribía yo que los únicos relatos de Sarduy antes de Gestos eran «Las bombas», «El general» $\mathrm{y}$ el 'cuento cubano' «El torturador», todos publicados en «Nueva Generación», página del periódico Revolución, a principios de 1959 (p. 729). A manera de corrección, el profesor Seymour Menton, de la Universidad de California, Irvine, me envió un recorte de «El seguro», sin indicación de su procedencia. Quiero expresar aquí mi agradecimiento al profesor Menton y hacer constar que fue él quien dio con «El seguro». La información bibliográfica completa de «El seguro» es: sección «Cuentistas Cubanos», "Ilustraciones de R. Fornés», en Carteles, núm. 33, 18 de agosto de 1957, pp. 66-67, 107. Dada la brevedad del cuento, me permito no indicar la página cuando lo cito en este trabajo, pero evidentemente toda cita proviene de las páginas indicadas de Carteles. 
Ya de por sí, la aparición del relato en Carteles es un dato de interés histórico, dado que el redactor de esa revista, que en sus inicios había sido nada menos que Alejo Carpentier, lo es Guillermo Cabrera Infante cuando Sarduy publica «El seguro». Es muy probable, por tanto, que la siguiente nota biográfico-crítica que acompaña el cuento haya sido redactada por el autor de Tres tristes tigres:

Severo Sarduy es muy joven: nació en 1937. Lo que nos hace afiliarlo a la última de las últimas generaciones literarias cubanas -a la misma del malogrado Leslie Fajardo, por ejemplo-. Actualmente alterna sus estudios de medicina con la composición de una novela, $E l$ hombre que amaba su reloj, que Sarduy ha calificado, momentáneamente, de surrealista. "Aunque no es exactamente surrealista, pues esta palabra puede originar un malentendido anacrónico», explica Sarduy, rápido. Es probable que su novela tenga muchas de las virtudes de «El seguro» y alguno de sus defectos (verbigracia: la influencia, tardía, de Kafka, cierta complejidad gratuita y la aparente falta de necesidad del lector). Pero esto, a los veinte años de Sarduy, no son defectos: son excesos ${ }^{2}$.

Poco tendría de surrealista la proyectada novela si en algo se parecía a «El seguro», pero quién sabe, tomando en consideración las alternativas que barajaba Sarduy entonces. En 1957 Sarduy era un escritor des-

\footnotetext{
${ }^{2}$ Ibid., p. 66. En carta del 22 de septiembre de 1979, Guillermo Cabrera Infante tuvo la gentileza de disipar mis dudas sobre el autor de la nota, y sobre Leslie Fajardo, cuyo nombre no me había sido posible ubicar. Cito in extenso de su carta, no sólo por lo que revela sobre Sarduy, sino también sobre Cabrera Infante: «En 1957 yo era el jefe de redacción de Carteles, que era un nombre demasiado grande para designar mis labores: leer literatura, inédita y édita, pues había una sección de cuentos extranjeros. En los cuentos cubanos pubïiqué el cuento de Severo, y la nota, como todas ellas entonces, la escribí yo. Como habrás visto, no siempre daba la nota. Leslie Fajardo (para más datos puedes leer mis Exorcismos de esti $(l) o$ ) fue un pobre muchacho, estudiante junto con mi hermano de la Escuela de Periodismo. Estaba lleno de contradicciones, algunas literarias. Admiraba a Hemingway, por ejemplo, pero sus cuentos eran absolutamente kafkianos, a quien no conocía. No lo conocí. Solamente me sometió a través de mi hermano dos cuentos y se fue por el verano, y nunca volvió. Su padre era policía, y una noche en que se quedó en su cuarto a leer hasta tarde, como acostumbraba, robó el revólver y se dio un tiro en la sien. Por la mañana lo encontró su madre. Nunca se supo por qué se mató. Pero yo, que conozco los dobles gajes de la adolescencia y del suicidio, sospecho que fue un acto gratuito. Siempre me sentí culpable con él porque pude haber leído esos cuentos antes de que se fuera al Mariel. Los publiqué los dos, uno en Carteles y el otro en la revista Ciclón, de Rodríguez Feo. Como ves, las publicaciones, las notas y la viñeta en Exorcismos fueron un pobre rescate de entre los muertos.»
} 
conocido para los lectores de Carteles, aunque no del todo para los escritores y artistas cubanos del momento. No sabemos si El hombre que amaba su reloj pasó jamás de ser un mero proyecto, y siempre podremos conjeturar si habría sido terminada de no haber venido la Revolución y reorientado la historia de Cuba, y con ella los proyectos de todos los escritores cubanos. Pero evidentemente el redactor evoca ese título para llenar un poco el curriculum de un principiante que con «El seguro» se daba a conocer al público cubano en general.

Ya en 1957 Sarduy había publicado poemas en periódicos de su nativa Camagüey, y sus versos de adolescente llegarían a ser recogidos en una antología local ${ }^{3}$. La larga tradición literaria camagüeyana - desde Silvestre de Balboa pasando por Gertrudis Gómez de Avellaneda, hasta Nicolás Guillén - da más peso a estos inicios y primicias de lo que pudiera pensarse. Camaguiey tenía una larga y viva tradición de actividad literaria, que el propio Guillén recuerda con afecto ${ }^{4}$. Pero, sobre todo, para 1957 ya Sarduy había publicado poemas y prosa en Ciclón, revista que, dirigida por José Rodríguez Feo, logró retener algo del prestigio literario de Orígenes, que había cesado su publicación en 1956 y de la que pretendía ser una prolongación. Como ya he indicado en otra ocasión, estos primeros poemas de Sarduy manifiestan el impacto de Lezama, a quien había leído Sarduy desde Camagỉey en ejemplares de Orígenes que le suministrara Rolando Escardó ${ }^{5}$. Lo mismo ocurre con un

${ }^{3}$ Colección de poetas de la ciudad de Camagiiey, ed. Samuel Feijó (La Habana: Ediciones del Grupo Yarabey, 1958). Para más detalles sobre la obra temprana de Sarduy, véase mi citado «Son de La Habana» y también «Para una bibliografía de y sobre Severo Sarduy (1955-1971)", en Revista Iberoamericana, núm. 79 (1972), pp. 333-343. Con ligeras enmiendas, esta bibliografía ha sido recogida en Severo Sarduy, selección y montaje Julián Ríos (Madrid: Editorial Fundamentos, 1976), pp. 177-192.

${ }^{4}$ «Por esos años [1918-20] me reunía con un grupo de poetas en la puerta de la administración de Correos de Camagïey, un edificio grande situado entonces donde está todavía, es decir, frente a la iglesia de las Mercedes. Allí discutíamos las últimas noticias literarias y esperábamos las diez de la noche, en que nos dispersábamos por los cuatro vientos de la ciudad. Entre esos poetas y escritores recuerdo a Arturo Doreste - hoy académico de la Española-, mucho mayor que yo -todos lo eran-; César Luis León, cuyo nombre verdadero era Eugenio Sánchez Pérez; Julio Milla Chapellí, que se ahorcó; Vicente Menéndez Roque, que se hizo médico y dentista y era, a mi juicio, el más fino de todos, pero ćndonó la poesía. Murió hace unos años. Había un español que era algo así com l animador del grupo; se llamaba Medardo Lafuente, y su voz era obligatoria en cuanto acto cultural había en Camaguiey, y desde luego en los entierros de importancia» («Conversación con Nicolás Guillén», en Casa de las Américas, núm. 73 [1972], p. 123).

${ }^{5}$ Fueron Escardó y Virgilio Piñera quienes introdujeron a Sarduy en el ámbito poético de Lezama. También influyó en Sarduy en esos años de adolescencia ca- 
poema como «Cautelas», publicado pocos meses después del triunfo de la Revolución en la Nueva Revista Cubana, dirigida entonces por Cintio Vitier, una de las figuras más importantes del grupo Origenes y amigo personal de Lezama ${ }^{6}$. El propio Vitier, en el prólogo a su programática antología Diez poetas cubanos: 1937-1947, ha caracterizado así la poesía del grupo, cuyo eco percibimos en «Cautelas»:

$\mathrm{Y}$ en efecto, a las bellas variaciones en torno a la elegía, la rosa, la estatua (típicas de la generación anterior y persistentes aún en otros países hispanoamericanos) sucede entre nosotros un salto, que diríamos en ocasiones sombrío de voracidad, hacia más dramáticas variaciones en torno a la fábula, el destino, la sustancia; el justo y transparente endecasílabo es abandonado por un verso imperioso e imprevisible; una poesía de penetración. Comprobamos así cómo el intimismo esteticista (usadas estas palabras en un sentido estrictamente descriptivo) se abre a la aventura metafísica o mística y, por tanto, muchas veces hermética. El poema, de más compleja melodía o alterado contrapunto, crece y se rompe por todas partes bajo la presión de ese universo desconocido y ambulante que de pronto ha querido habitarlo, y cada poeta inicia, estremecido por la señal de José Lezama Lima en «Muerte de Narciso» (1937), la búsqueda de su propio canon, de su propia y distinta perfección ${ }^{\text {? }}$.

Me temo que «Cautelas» no alcanza el fulgor poético de Lezama. Pero es en este poema de 1959 donde Sarduy más se aproxima a la voz del maestro (a quien mucho más adelante reescribirá con mejor pulso). Cito el tercer fragmento de cuatro que componen el poema:

Del verdadero Paraíso hablo:

Con qué furia los ángeles golpean

el cuerpo luminoso de las aves.

Quiebran sus alas, sexos y cabezas, oyen sus textos en pasión, buscando el verdadero centro del lenguaje:

magüeyan? zetisa Clara Niggeman. Fue ella quien le reveló los misterios de la teosofía, io introdujo también a la obra de Krishnamurti (su primer contacto con el mundo indio) y le ayudó a publicar algunos poemas en El Camagüeyano.

' Nueva Revista Cubana, año 1, núm. 1 (1959), pp. 110-111.

${ }^{7}$ Diez poetas cubanos, antología y notas de Cintio Vitier (La Habana: Ediciones Origenes, 1948), p. 10. 
«No es lo hablado en sí mismo, sino el habla.

El cuerpo es de su voz indivisible

y la palabra ángel no es un ángel.»

No es la luz de sus ojos lo que mira;

sino el aire por ellas no volado.

Sino el aire por ellas no volado (p. 111).

La temática de la inadecuación del lenguaje, tan explícitamente formulada, anuncia más al Sarduy futuro que al joven devoto de Lezama; pero las reiteraciones, el ritmo y sobre todo el fervor teológico del poema es típico de lo expuesto por Vitier. Hasta mediados de los sesenta, cuando ya el impacto de Tel Quel y cierta temática parisiense invaden su obra, hay en la poesía de Sarduy claros ecos de un Lezama no re-escrito, sino repetido. Quizá esa dificultad de escribir poemas sin repetir a Lezama haya llevado a Sarduy paulatinamente hacia la narrativa, aunque en realidad su obra madura es de tal complejidad que difícil sería aceptar determinaciones de esta índole.

Ahora bien: si en poesía Sarduy manifiesta una afinidad evidente con Lezama y el grupo Orígenes, muy otra es su orientación en cuanto a prosa narrativa, según revela de inmediato «E1 seguro», y como se reitera en «El torturador», «Las bombas», otros textos de 1959 y hasta en su primera novela publicada, Gestos (1953). Todas estas obras, aunque ya en menor grado Gestos, se inscriben dentro de la tendencia realista de narrativa de protesta social, que tiene una larga tradición en Cuba, desde Cecilia Valdés y la novela anti-esclavista hasta las obras àe Carlos Loveira, Carlos Montenegro, Félix Pita Rodríguez, Lino Novás Calvo, Enrique Serpa y otros ${ }^{8}$. Quien sólo tenga presente al Sarduy de De donde son los cantantes (1967), Cobra (1972) y Maitreya (1979) apenas podría imaginar que haya vínculo alguno entre éste y los autores mencionados. Pero lo cierto es que, en prosa narrativa, el Sarduy de los cincuenta tiene más en común con Marcos Antilla, de Luis Felipe Rodríguez, que con tendencias más vanguardistas de narrativa. Hasta Gestos, cuando, como he argüido en otra parte, hay una parodia de la narrativa realísticohistórica pre y posrevolucionaria y una apertura hacia un texto mixto y complejo, como De donde son los cantantes, el Sarduy poeta y el Sarduy narrador son aparentemente tan distintos el uno del otro como dos autores diferentes ${ }^{9}$. Ello a pesar de declaraciones como la siguiente,

\footnotetext{
${ }^{8}$ Hoy Sarduy recuerda la influencia de Piñera como más decisiva, aun en «El seguro». Véase nota 13 más adelante.

" «Son de La Habana», op. cit.
} 
hecha un mes después del triunfo de la Revolución: «Sí, queremos arte nacional, pues puede hacerse pintura nacional sin llenar los cuadros de guajiros y palmas; puede hacerse teatro nacional donde no aparezcan gallegos y negritos; puede hacerse poesía nacional que no cante a los turistas y los soldados... ${ }^{10}$. No cabe dudar de que esta dualidad en Sarduy refleja un desajuste similar en la historia de las letras cubanas, producido en parte por circunstancias políticas muy concretas. Me refiero a que si bien la poesía había seguido un desarrollo rápido a partir de la vanguardia, en parte porque su propia marginalidad y limitada circulación la hacían inocua a los gobernantes de turno y las vicisitudes de la sociedad, la novela no se había desarrollado con igual ímpetu por falta de público y por ser más susceptible a la censura. Aunque en 1953 Los pasos perdidos se publicó en México en edición sufragada por Carpentier, y $E l$ acoso, del que había salido un fragmento en Orígenes, se publica en 1956, pero en Buenos Aires, cuando en 1952 Carteles, con motivo del cincuentenario de la República, hace un recuento de la novela cubana hasta ese año, Carpentier no figura todavía ${ }^{11}$. La renovación de la novela cubana, inclusive la ya llevada a cabo antes de 1959, sólo se conoce en amplitud después del triunfo de la Revolución.

También hay que tener presentes dos factores externos más. El primero y más evidente es que Carteles era una revista de amplia circulación, no una revista literaria, donde aún «El seguro», que, según veremos, es

${ }^{10}$ «Pintura y revolución», en Revolución, 31 de enero de 1959, p. 14 (citado en «Son», op. cit., p. 730). Sin embargo, en «Grabados/esculturas», Sarduy escribe:

En un momento, un cuadro abstracto puede funcionar tan bien como uno figurativo; un poema intimista tan bien como uno social; tengamos en cuenta ahora que estamos en un momento determinante de la historia de Cuba. Quien, ya disfrutando del triunfo absoluto de la Revolución, examine dentro de algunos años el resultado. intelectual de esta etapa de fervor y júbilo, quizá pueda decir que la cautela de nuestros artistas les impidió panfletar y comprometerse hasta la saciedad con el presente histórico, del cual no quedaron más poemas que el escrito por las manos hinchadas y poderosas del pueblo ni más murales que la imagen, en el recuerdo, de los machetes que se alzan y chocan en el aire produciendo la más conmovedora de todas las músicas, que toca las manos del obrero, de las cuales, intacta, blanca, tierna y poderosa, brota, rebelde, la nueva paloma de la Paz» (en Artes Plásticas, núm. 1 [1960-61], p. 34).

En este mismo número Sarduy también pubiica «De la pintura en Cuba» (p. 16). Estos trabajos no figuraban en mi «Para una bibliografía» (op. cit.) ni tampoco fueron tomados en cuenta al redactar «Son de La Habana».

${ }_{11}$ «El ensayo, la novela y el cuento en la literatura cubana», en Carteles, número 20, 18 de mayo de 1952, pp. 138-141. Carpentier le reveló al autor, en 1979, que había pagado la edición de El reino de este mundo y Los pasos perdidos. 
de escasa densidad, puede parecer al editor «de una complejidad gratuita». Pero también hay que recordar que 1957 es un año de recrudecidas luchas contra la dictadura de Batista: 1957 es el año del ataque al Palacio Presidencial por parte del Directorio Revolucionario, y ya se han afianzado en la Sierra Maestra las fuerzas de Fidel Castro. Sarduy, estudiante universitario y además de familia proletaria, no podía sustraerse al compromiso político que el momento exigía ${ }^{12}$. Si bien hay rasgos en «El seguro» que podrían referirse a Cuba en cualquier momento de la era republicana, dado el momento en que se publica, hay que verlo como reacción a los acontecimientos políticos de que surge. Junto con las «Décimas revolucionarias», hay por ello que ver «El seguro» como parte de un momento de literatura comprometida en la obra de Sarduy; pero habría que añadir que el compromiso es mucho más evidente y conlleva muchos más riesgos concretos en el caso de «El seguro», publicado en una revista de amplia difusión y en una época de extraordinarias tensiones políticas.

En todo caso, «El seguro» se inscribe cómodamente en la tradición realista de narrativa de protesta al estilo de Félix Pita Rodríguez, Luis Felipe Rodríguez, ciertas obras de Lino Novás Calvo y Enrique Serpa, y hasta del Carpentier temprano de iÉcue-Yamba-Ó! e «Histoire de lunes». La anécdota es la siguiente. A un cortador de caña le ofrecen un seguro contra accidentes del trabajo. Aunque apenas entiende los términos de la póliza que le venden representantes de una agencia norteamericana, el campesino se entusiasma pensando que tal vez con el dinero que algún día cobre logrará educar a su hijo. Con grandes sacrificios el cortador paga las cuotas. Pero un día su hijo se enferma de gravedad, y sin fondos para atenderlo, toma una decisión drástica. Hace que su amigo Basilio le corte varios dedos de una mano con un machete y se presenta en las oficinas de la compañía de seguros a cobrar la indemnización. Pero el médico de la compañía descubre la artimaña al revelarle el cortador que es derecho, ya que la mano mutilada es la derecha. Se le niega el pago y el obrero sale corriendo desesperado hacia su casa, donde se encuentra a Basilio, quien le ayuda a construir con unos cajones un ataúd para su hijo, que ha muerto de la enfermedad ${ }^{13}$.

${ }^{12}$ Las mejores fuentes publicadas sobre la biografía de Sarduy se encuentran en Severo Sarduy (op. cit.), en particular el fragmento redactado aparentemente por la madre del escritor y la "Cronología» escrita por Sarduy mismo. El padre de Sarduy era empleado ferroviario.

${ }^{13}$ Sobre «El seguro», Sarduy dice lo siguiente en carta del 23 de julio de 1979: «Hay algo, sin embargo, que por honestidad intelectual no puedo ocultar: 1) el cuento, tal y como está, no es más que una versión incompleta, sea porque no 
El tono de protesta es evidente en «El seguro» no sólo por el drama de su anécdota, sino sobre todo por los detalles específicos de la historia político-social que evoca. Al principio, cuando llegan los vendedores de seguros, el campesino cree que éstos son americanos, pero resultan ser cubanos. La mayor aspiración del cortador es que su hijo "hablara en inglés, como el hijo del jefe de estación, con los americanos y "jamaicanos'». El nombre de la compañía de seguros está en inglés: «Comenzaron hablando del tiempo hasta que uno de ellos, señalando un letrero en dorado que había en el frente de una de las carpetas de cuero que traían, le dijo que pertenecían a una nueva compañía de seguros, y pronunció un nombre en inglés que parecía ser el mismo que estaba en la carpeta.» El tipo de engaño a que es sometido el campesino es también de una especificidad histórico-social que subraya el carácter acusatorio concreto del texto. En una obra como ¿Écue-Yamba-Ó!, los campesinos son víctimas del desalojo gradual de sus tierras; desalojo del que son víctimas por el expansionismo de las compañías azucareras norteamericanas. Se trata de un proceso histórico-social típico de zona rural. Pero una vez enajenados de sus tierras, los campesinos se convierten en obreros, y pasan a formar lo que Sidney Mintz ha llamado un proletariado rural ${ }^{14}$. El campesino de Sarduy es un proletario rural, y la venta de un seguro contra accidentes, un tipo de relación económica de tipo urbano trasplantada al campo. Es decir, aunque «El seguro» entronca con la tradición de un Luis Felipe Rodríguez o un Carpentier temprano, no narra conflictos de tipo «feudal», que ya han caducado en la propia realidad social de la isla. No se trata de las pugnas por un pedazo concreto de tierra, sino de relaciones ya más abstractas, de intercambio de valores menos tangibles aún que el mismo dinero. Al campesino ya le han robado el pasado y el presente: en «El seguro» le roban lo más abstracto que le queda, el porvenir. El euento de Sarduy, por tanto, protesta contra las condiciones concretas de la industria azucarera del momento: la industria

cupo en la revista o porque yo mismo lo alteré antes de la publicación: en realidad, el esquema narrativo era menos ingenuo, y que constaba de una especie de anticlímax: el seguro se concedía cuando ya era tarde, venían a avisar que se otorgaba y se encontraban con el cadáver, o algo así; 2) hay que reconocer, aparte de la constancia de mis temas, de mis figuras y retóricas, que hacen de mí no un escritor, sino un obsesional - la venta apócrifa de seguros y casi el mismo maletín están en Maitreya-, la influencia enorme que en ese momento tuvo en mí Virgilio Piñera, el Quevedo cubano del Góngora que es Lezama, hoy marginado y olvidado. No sólo el mood general del cuento, sino hasta frases como "discreta pero burlona', etc., vienen de él. Eran, si mal no recuerdo, los tiempos de Ciclón.»

${ }^{14}$ Sidney Mintz, «Foreward», en Ramiro Guerra Sánchez, Sugar and Society in the Caribbean (New Haven: Yale University Press, 1964), pp. xi-xliv. 
azucarera de la segunda posgtierra. Por arcaico que nos parezca en principio «El seguro», su temática sociopolítica no es tan retrasada, sino que, por el contrario, estaba muy al día en su momento.

De este tipo de explotación más moderna, Sarduy ofrece aún más detalles en el cuento, ya que por esas fechas él mismo trabajaba en una agencia publicitaria, y de seguro habría visto por dentro el manejo de ese tipo de manipulación comercial. Otros escritores e intelectuales cubanos - Manuel Moreno Fraginals, Alejo Carpentier y Guillermo Cabrera Infante- también se ganan la vida en la publicidad, y muchos otros lo hicieron en la radio. La publicidad suscita todos los debates sobre la retórica que surgieron alrededor de los sofistas; debates de los que se nutre la propia literatura. No es por mero azar ni por un simple determinismo económico-social que los escritores gravitan hacia la publicidad y el mundillo de la farándula, que Cabrera Infante en Tres tristes tigres, César Leante en Muelle de caballerías y Carpentier en La consagración de la primavera evocan ${ }^{15}$. La publicidad, la radio, la televisión, son actividades perversamente paralelas a la literatura (o a la pintura, la música, etcétera), con la atracción de que en ellas se puede ganar la vida el artista. Hay que tener presente además que Cuba fue la cabeza de playa de la avanzada de la televisión norteamericana hacia América Latina, y con ésta surgieron las compañías publicitarias de alto vuelo ${ }^{16}$. La televisión tuvo tal impacto en la historia de Cuba, que hay quienes han sostenido que sin ella la Revolución no se habría podido solidificar en el poder. En cuanto a la literatura cubana, habrá que hacer algún día un estudio pormenorizado de las relaciones de ésta con la radio, la televisión y la publicidad. Significativamente, quien más ha especulado de forma irónica sobre el asunto ha sido Carpentier, primero en Los pasos perdidos, pero más explícitamente en La consagración de la primavera, donde se lee:

Si Miguel Angel hubiese nacido en Cuba, en vez de pintar Ia Capilla Sixtina habría embadurnado vallas anunciadoras para la pasta Colgate o el jabón Palmolive. Por lo mismo, a tiempo me pasé del campo de Leonardo o del Tintoretto al campo de César Biroteau -pregonero genial del Aceite Cefálico, del Agua Carminativa, de la

${ }^{15}$ Sobre César Leante y sus contactos con la radio, así como las relaciones de otros artistas de su generación con los medios de comunicación masiva, véase William Luis, "César Leante: The Politics of Fiction" (Ph. D. Dissertation, Cornell University, 1980).

${ }^{16}$ Véase la «Introducción» a Azriel Bibliowicz, «Lo público es privado: un análisis de la televisión colombiana» ( $\mathrm{Ph}$. D. Dissertation, Cornell University, 1979). 
Doblecrema de las sultanas, «invento de un médico árabe, muy usada en los surallos»-, antecesor y santo patrón de todos los publicitarios del mundo, por obra y gracia de Honorato de Balzac. «La facilidad de palabras debe serle muy útil en sus actividades» - dije--. Está usted en lo cierto, porque mi profesión es la más hamlética de todas: Words, words, words - lo que equivale a decir: slogans, slogans, slogans...-. No los hay mejores que: To be or not to be, alas, poor Yórick, que se mantienen frescos y activos desde hace cuatro siglos y servirían maravillosamente hoy para inducir al poseedor de un Morris a cambiarlo por un Lincoln o un Cadillac... Al comienzo fue el verbo, dijo San Juan. Y el Verbo engendró la primera Agencia de Publicidad. Fiat Lux!, dijo Dios. Y al punto se encendió el primer anuncio lumínico ${ }^{17}$.

Más adelante Carpentier hace leer a uno de sus personajes el siguiente pasaje de Marx:

Todo hombre se afana en crear para otro una necesidad nueva para inducirlo a hacer un nuevo sacrificio, colocarlo en una dependencia nueva y llevarlo hacia nuevas modalidades de goce... La multiplicación de productos es el cebo con el cual se trata de atraer al otro, sacándole su dinero, ya que toda necesidad real o posible es una debilidad que atraerá a la víctima con la sonrisa más amable, diciéndole: «Querido amigo: yo te daré lo que necesitas...» El eunuco industrial se inclina ante los más infames caprichos del hombre, oficia de alcahuete entre sus necesidades y él mismo, atento a sus muchas debilidades, para exigirle luego el salario correspondiente a sus buenos oficios...18

En «El seguro» hay muchos detalles significativos que provienen del ámbito de la publicidad, es decir, de aquella práctica del signo encaminada a persuadir y engañar al consumidor: «Le hablaron de la compañía con muchas palabras largas y difíciles que él no entendió muy bien, no sabe si porque no las había oído antes o por lo rápido que las dijeron, como si no quisieran disimular que se las sabían de memoria.» Ya desde la misma apertura del cuento el uso del lenguaje había sido causa de un equivoco: "Como creía por su indumentaria que los vendedores eran americanos, se quedó asombrado de que dieran los buenos días en perfecto castellano, y entonces comprendió que se había equivocado.» Ahora, frente al campesino, los vendedores hablan de memoria -repiten palabras que no expresan «espontáneamente»- e invocan

\footnotetext{
${ }^{17}$ (México: Siglo XXI Editores, 1979), pp. 334-335.

${ }^{18}$ Ibid., p. 345.
} 
trucos típicos de la publicidad de la época: «Le hablaron de una casa y terreno que podía obtener pagándolos en cómodos pagos si antes su número no resultaba premiado en un sorteo que la compañía celebraba mensualmente.» Después del «accidente», cuando el campesino acude a las oficinas de la compañía de seguros, hay una reaparición irónica de estas promesas: «Llegó pronto al pueblo y encontró la casa de la compañía de seguros. El salón principal era espacioso y muy limpio, aunque quizá algo oscuro. En una de las paredes estaba incrustado con grandes letras doradas el nombre de la compañía. En las otras tres había colgados varios cuadros con los reglamentos y las gráficas del número de asociados, así como enormes fotos de dos de éstos, cuyos números habían sido premiados con una casa, en el momento de recibir las llaves.» No hay más que ojear la misma revista en que aparece el cuento de Sarduy para percatarse de la presencia en la Cuba de la época de la propaganda comercial a gran escala. «El seguro» es una denuncia de la falsedad sistemática, del engaño institucionalizado que representa la publicidad. Los mensajes que rodean y atolondran al campesino lo impulsan a vender su propia carne, literalmente, lo cual de por sí indica hasta qué punto ha llegado la mixtificación, ya que lo que le interesa a la compañía es el valor de esa carne como instrumento de trabajo por un período de tiempo lo más largo posible. No es por azar que tanto el Cabrera Infante de Tres tristes tigres como el Sarduy de estas primicias evoquen ese mundo quevediano de la publicidad en el cual vivían inmersos y del cual tenían a veces que vivir. El mismo Sarduy que escribe «El seguro» es el autor de la letra de un jingle anunciando una marca de zapatos, que se cantaba con la música del himno de los U. S. Marines. "From the Halls of Montezuma, to the shores of Tripoli» se convierte en "California, California, California a los pies de usted ${ }^{19}$. No sabemos si la parodia inspiró a Sarduy o si tuvo él algo que ver en la selección de la música, pero en todo caso lo que caracteriza el lenguaje publicitario es la ausencia de jerarquías o su confusión deliberada para persuadir a ultranza al consumidor. La preocupación — política, social - por el lenguaje que se manifiesta en «El seguro» no está lejos, aunque allá sea una preocupación más trascendental, de "Cautelas» - «y sus textos con pasión, buscando / el verdadero centro del lenguaje...»-. El campesino de «El seguro» es víctima de un lenguaje que no logra descifrar, que lo aparta sistemáticamente del sentido, que explota su incomprensión. Las confusiones —desde la inicial sobre la nacionalidad de los agentesplagan el mundo textual del cuento. Sólo que el campesino, cuando

\footnotetext{
19 Información suministrada al autor por Sarduy en París en 1973.
} 
quiere él engañar convirtiendo su cuerpo en signo, sufre una especie de metalepsis, una sustitución que lo descubre: la escritura lo traiciona. $\mathrm{Si}$ los agentes manipulan unos códigos que lo engañan, el campesino no puede manipularlos para engañarlos él a ellos. Los vendedores mismos hablan «de memoria», son meros conductores de esos códigos; el engaño inherente al código publicitario no da lugar a la intencionalidad individual. El ámbito de las mutaciones del lenguaje es tan violento como el evocado en «Cautelas»: "Con qué furia los ángeles golpean / el cuerpo luminoso de las aves. / Quiebran sus alas, sexos y cabeza...»

¿No habrá debajo de las evidentes discrepancias un nódulo de actitudes ante el lenguaje que aproximen «El seguro» y «Cautelas»? ¿Serán sólo superficiales las diferencias entre estos textos? ¿Habrá un centro formado de temas y obsesiones que marquen desde el inicio la obra de Sarduy? ¿Será la evolución posterior de Sarduy una simple ampliación de lo que es ya, desde los cincuenta, una obra?

No cabe duda de que hay en «El seguro» una serie de rasgos que nos es lícito proyectar hacia el futuro de la obra sarduyana. Por ejemplo: la problemática del lenguaje que hemos venido observando es una constante en la obra de Sarduy, y no simplemente en este sentido vago y abstracto. Hay detalles, como la fijeza del texto en el rótulo de la carpeta $o$ en las paredes de la compañía de seguros, que se repetirán en todas las obras de Sarduy: es el tópico que pudiésemos denominar del texto fijo en su inscripción, pero paradójicamente móvil en su significado. Hay hasta en las letras doradas de la inscripción un adelanto del neobarroco que caracterizará más adelante la obra de Sarduy. Es más: tal vez no sea aventurado decir que «El seguro» gira en torno a un texto: la misma póliza, cuya (falsa) promesa es en términos mallarmeanos abolir el azar. En cierta medida, todos los engaños promovidos por el lenguaje en el cuento encarnan en este texto, que puede verse como una especie de figuración del lenguaje literario mismo. Por último, el gesto de mutilación con el propósito de engañar por parte del protagonista puede verse como un acto de escritura corporal, similar al de otros personajes sarduyanos - la cifra última de un lenguaje, cuya única confiabilidad es stl inscripción, es el cuerpo mismo, cuyo postrer mensaje es una autorreferencialidad radical. Visto desde esta perspectiva, «EI seguro» empieza a manifestar características que lo alejan considerablemente de la tradición cuentística cubana de que hablamos antes, y que anuncian, si bien de forma incipiente e indecisa, algunos de los rasgos sobresalientes de la novelística hispanoamericana de los sesenta y setenta.

Hay elementos aún más concretos en «El seguro» que reaparecerán en obras más maduras de Sarduy. A pesar de las radicales divergencias 
entre este cuento y Cobra, por ejemplo, no podemos pasar por alto que en ambos textos la acción gira alrededor de una automutilación, de una ablación premeditada a la que se somete el personaje principal. Desde luego, en Cobra la operación que sufre el protagonista forma parte de una compleja red de alusiones al pensamiento francés postestructuralista, más concretamente a las teorías de Derrida sobre la escritura y el suplemento. Cobra es el mundo de la escritura, de la suplementariedad, del falo cercenado, superfluo, vuelto a injertar. No sería difícil, ateniéndonos a un freudianismo un poco burdo, ver en la mutilación de los dedos del campesino una especie de castración simbólica. Pero más interesante sería lograr ver la violencia contra su propio cuerpo, el marcarlo de tal manera como una especie de escritura corporal, según vimos antes, que entra en juego con el texto (ausente) de la póliza de seguros - la inseguridad de la póliza, si se me permite, va a ser suplida por la falta de los dedos-. La escritura hace presente lo ausente, pero la escritura es aquí también una ausencia, un corte. Hay además un personaje -el médico- que parece repetirse en «El seguro» y Cobra. En «El seguro»:

En ella [la sala de consultas] había solamente un sofá larguísimo y una mesa, detrás de la cual apareció un médico de pequeñísima estatura, rechoncho, de enorme cabeza calva que soportaba unos lentes muty grtuesos detrás de los cuales brillaban unos ojos pequeños, diminutos. Tenía una vocecilla desagradable, extraordinariamente fina, femenina si se quiere. Se paró pesadamente con aire de indiferencia. Tomó la mano ensangrentada y la vendó. Entonces comenzaron las interrogaciones.

En Cobra, el doctor Ktazob aparece dibujado con rasgos mucho más precisos, pero que conservan tanto la feminidad como la indiferencia imperiosa del médico de «El seguro»:

Lo más difícil -Ktazob tenía el pelo plateado, era adicto a las viñetas villaclareñas de Partagás y a los árboles de subordinadas. Una tosecita, o más bien un pujido [s] eco, como de quien tiene que disimular, en el testículo derecho, un aguijonazo de jején, culminaba las vaharadas vueltabajeras y las frondas sintácticas. Un suéter negro apretado no afinaba ya la cupoleta ventral ni los caudales hemisféricos, rotundos. De ademanes: parsimonioso despótico de tono; lentes; pupilas de palomo-, lo más difícil no es la formalidad final, cuestión de minutos, sino el aprendizaje previo para transferir el dolor, y subsiguiente, para eliminar la sensación de carencia ${ }^{20}$.

${ }^{2 y}$ (Buenos Aires: Editorial Sudamericana, 1972), p. 105. 
La figura del médico junto con la automutilación y la presencia del lenguaje de la publicidad son los recuerdos del porvenir más concretos en «El seguro», pero hay otros rasgos generales que conviene mencionar.

Lo voluptuoso tanto del lenguaje de Sarduy como de los escenarios de las obras maduras hace pasar por alto que la inmensa mayoría de los personajes de su obra, como los de «El seguro», provienen de las clases pobres. En Gestos este aspecto es de suma importancia y es lo que en cierta medida determina el desarrollo del argumento. La cantantelavandera traduce al lenguaje de la novela radial su propia acción revolucionaria y su relación con el amante blanco, que es de una clase superior a la suya. E1 lenguaje de la publicidad y los mass-media ha invadido el cerebro de la cantante-lavandera hasta el punto que aparece ella como inscrita en una serie de textos que no comprende. Auxilio, Socorro, Cobra, la Cadillac, las Tremendas y otros personajes sarduyanos llegan a celebrar, por el uso que hacen de él, la ausencia de jerarquías, la ausencia de moral y veracidad del lenguaje de los mass-media. Todos estos personajes son de origen humilde, y su empleo del lenguaje publicitario es una irrisión tanto de los valores que promueve como de la cultura en general. Si bien la evidente intencionalidad política de «El seguro» se ha perdido después de Gestos, los textos de Sarduy continúan haciendo resaltar la falsedad sistemática y la pluralidad crítica de la comunicación en el mundo moderno. $Y$ lo hace a través de personajes -criaditas, prostitutas caras y baratas, travestidos, proxenetas, etc.que en los márgenes de la sociedad aprovechan la ausencia de jerarquías, la explosión de los códigos en los medios de comunicación. En «El seguro», la póliza misma es el anuncio de esa textualidad ebria de las ciudades modernas que la obra más reciente de Sarduy despliega. En este sentido, la obra de Sarduy es más «realista» que el realismo que cierta crítica anacrónica exige todavía a la literatura latinoamericana. Quien conozca las capitales de lo que hoy se llama el Tercer Mundo verá que en el neobarroco de Sarduy hay un elemento de realismo casi documental (a veces estrictamente documental, ya que el texto de la obra incorpora literalmente los recursos de los textos que se ven como grafitos o anuncios publicitarios). La lectura que hace Sarduy de la India o de Marruecos - - figuras de la América, por la historia común, elemento arábigo de la cultura hispana, o por error histórico, Indias Occidentales - es una especie de reflejo de las ciudades hispanoamericanas, a contrapelo de la lectura más convencional que hacen, por ejemplo, un Octavio Paz o un Cortázar. En Paz y en el Cortázar de Prosa del observatorio, la India es un lugar de origen: fuente de la cultura, origen vivo de la tradición, inicio recuperable del inicio. En Sarduy, por el contrario, esa India es la 
del American Express, cachivaches fabricados para turistas, chucherías en tableros de vendedores ambulantes; es decir, el mundo de los residuos de la cultura india, fragmentada, dispersa y de escombros del mundo postindustrial con sus propios residuos. Lo más «universal» es una chapa de Coca-Cola. En «El seguro», la invasión del ámbito campesino, receptáculo de la tradición autóctona del país, prefigura ese mundo de ruinas y desechos, de bricolage: «Entre los dos, con sólo dos cajones viejos y algunas telas, prepararon la caja.» En Cobra: «Dando vueltas alrededor del cadáver - le pegó la cabeza a las rodillas, los calcañares a las nalgas-, a partir de los pies lo fue envolviendo con esparadrapos, fajándolo, inocente embarro vidriado. Entre las bandas blancas, en los muslos, le quedaban adherencias acuosas, huesos paralelos, finísimos, que se partían: un ribete rojo, como de párpado; bajo la piel transparente se abrían minúsculas flores capilares, negras. Así empaquetado - embrión y momia- - lo dejó en una esquina, recostado al refrigerador y contemplando un lavaplatos eléctrico» ${ }^{21}$.

La diferencia entre «E1 seguro» y la obra más reciente de Sarduy es de todos modos notable. En «El seguro» hay una intencionalidad visible en la «Voz» centralizadora del narrador, que se supone no forma parte de ese lenguaje desasido, fragmentado de textos como Cobra o Maitreya. En la obra madura de Sarduy se ha superado ese dualismo, que en «El seguro» escinde el lenguaje entre un sujeto supuestamente libre de los condicionamientos del objeto que describe y representa. En la obra madura de Sarduy todo es representación: el lenguaje es como las cosas en el mundo moderno, que fueron alguna vez significativas, pero habitan hoy una especie de rastro de la comunicación, desde donde proyectan a veces destellos accidentales; reflejos de un sol unánime, imparcial, sin tiempo, que indiferente las ilumina en un mediodía cósmico.

Pero, no obstante, podemos ver en «El seguro» rasgos que anuncian elementos de obras futuras de Sarduy y otros que llegan a convertirse en constantes de su obra. También podemos descubrir que algunos elementos de su obra madura que parecen responder sobre todo al impacto de Tel Quel y la ideología estructuralista y postestructuralista constituyen más bien el desarrollo de intereses que surgen en la época habanera de Sarduy. Por ejemplo: la preocupación por lo cubano en una obra como De donde son los cantantes ha de verse como reflejo de una temática muy del grupo Orígenes, que cristaliza en el célebre libro Lo cubano en la poesía, de Cintio Vitier, y la temática, constante en Sarduy, de la rela-

${ }^{21}$ Ibid., p. 191. 
ción entre la pintura y la literatura es también producto de preocupaciones muy típicas del grupo Origenes, que fue tanto un movimiento poético como pictórico. Además, una de las características más sobresalientes de la poética de Lezama es su insistencia en la imagen. También vimos, por supuesto, que la temática del lenguaje, que luego va a aparecer con tanta insistencia en la obra madura de Sarduy, aflora ya en «El seguro». Pero es precisamente allí donde Sarduy, sin duda, rompe con Lezama y el grupo Orígenes para insinuar rasgos esenciales de su obra reciente. La temática del lenguaje acerca y aleja a la vez «El seguro» de «Cautelas» y de Lezama.

«El seguro» sugiere ya una noción del signo que va a fundamentar obras como De donde son los cantantes y Cobra; la sugerencia es desde luego temática, ya que no constituye parte misma de la elaboración del texto; pero aún así su efecto es apuntar a un vacío allí donde había de constituirse el texto. La póliza de seguros es un texto presente por sus efectos putativos o por su ausencia; está sin estar, es pura autorreferencialidad. Anticipando el impacto de Derrida en su obra, la póliza de seguros en el cuento de Sarduy es pura suplementariedad; el corte de los «dedos/falo» del protagonista viene a ser la hipóstasis de esa suplementariedad. La literatura de Sarduy va a girar en torno a esa noción de escritura, que va a encontrar apoyo teórico en la obra de estructuralistas y postestructuralistas. Claro, la relación de los textos de Sarduy con esa ideología no es inocente, y Cobra viene a ser una alegoría irrisoria del «pensamiento» postestructuralista, según he apuntado alguna vez antes. No obstante, aun cuando lo que queda de esa escritura es la positividad de unos signos, por variados o ausentes que quieran ser, lo cierto es que una suerte de teología negativa, perversamente similar a la cábala, es lo que rige ese mundo. En Lezama, por el contrario, hay un intento serio, intenso, hasta solemne, por fundar una teología positiva: por fundar una imagen presente y plena concebible en un mundo tan arcano hoy para nosotros como la patrística. Lezama es un escritor premoderno que pretende fundar su sistema poético en un materialismo espiritual, o un idealismo encarnado que sólo podemos pensar en términos cristianos. En Sarduy, el mundo es de residuos; en Lezama, palabras y cosas están imantadas por la fe. A pesar del enorme impacto que Lezama tiene sobre Sarduy, el Sarduy maduro no repite a Lezama, sino que lo re-escribe del lado de acá de la modernidad, apuntando al escándalo de incoherencias lezamianas, que sólo lo son en el ámbito donde la cosa y lo que significa ya han dejado de ser uno.

En sendos ensayos recientes de enorme poder sugestivo, Michel Foucault y Roland Barthes han meditado sobre el sentido del concepto de 
obra, grupos de textos cuya filiación establece la crítica y cuya coherencia garantiza la noción de autor ${ }^{22}$. Para Barthes, la obra es institucional, salvaguarda el sentido de lo escrito, mientras que el texto hace transgresión constantemente de todas las reglas, aun las de su propia producción. Foucault ve en la noción de autor un mecanismo ideológico que a posteriori limita las posibilidades de significación de un texto. La lectura que acabo de hacer de «El seguro», lo más saturada posible de información relativa al autor y afiliada de la forma más rigurosa posible a una tradición, nos permite sopesar el asunto. Es evidente que si la noción de autor significa coherencia ideológica tanto en momentos aislados como en una evolución, «El seguro» nos demuestra lo contrario: los textos de Sarduy, en un mismo momento de su carrera, son con frecuencia contradictorios, irreductibles a una síntesis racional coherente, a un discurso que no esté dispuesto a contener las contradicciones. Hay que admitir además que la lectura más explosiva del cuento, la que relaciona la inseguridad constitutiva de la escritura con la «seguridad» prometida de la póliza, no depende del contexto biobibliográfico del que he partido aquí. Habría sido posible relacionar la póliza con la marca/ausencia de los dedos del campesino sin recurrir a Cobra; o la inseguridad de la póliza y el letrero en la pared sin tener que recordar ningún otro texto de Sarduy.

A un nivel más práctico, sin embargo, el no saber que «El seguro» es de Sarduy nos habría llevado probablemente a leerlo como un cuento más de la tradición cubana que evoca la vida de privaciones y abusos sufrida por los campesinos. El nombre del autor sirve para alertarnos a las posibilidades de que el cuento sea distinto, promoviendo, en contra de lo que dicen Foucault y Barthes, una lectura más rica en posibilidades; la noción de autor o el concepto de obra no pueden ocupar ya el lugar determinante que la crítica les asignaba, pero ambos son elementos constitutivos de todo texto «literario» que tampoco podemos suprimir o ignorar. Queda además el hecho difícilmente discutible de las constantes que ya aparecen en «El seguro», que tienden no sólo a confirmar la validez de la noción de autor, sino que evidentemente encauzan la lectura hacia una reducción. La respuesta a estas paradojas, creo, es que tanto Barthes como Foucault manejan nociones demasiado estrechas de autor y obra. La obra/autor que la crítica debe incorporar está hecha

${ }^{22}$ Ambos ensayos han sido recogidos, en traducción inglesa (Barthes, «From Work to Text»; Foucault, «What is an Author»), en la útil antología de Josué V. Harari publicada bajo el título de Textual Strategies. Perspectives in PostStructuralist Criticism (Ithaca: Cornell University Press, 1979). 
de contradicciones, atravesada por varias formas de producción, hecha de elementos inherentemente opuestos; no basada en una noción simplista ni de vida ni de conciencia creadora que excluya lo irreductible al discurso racional o a una noción teleológica o evolutiva de la carrera del escritor. 